\title{
The aggressiveness of pig slurry to cement mortars
}

\author{
J. Massana , A. Guerrero , R. Antón , M.A. Garcimartín , E. Sánchez
}

\begin{abstract}
The aim was to measure the behaviour of various mortars employed in livestock media in central Spain and to analyse the aggressiveness of pig slurry to cement blended with flyash mortars. To achieve this, mortar specimens were immersed in ponds storing pig slurry. Mortar specimens, of $40 \times 40 \times 160 \mathrm{~mm}$, were made from four types of cement commonly used and recommended for rural areas. The types were a sulphate-resistant Portland cement and three cements blended in different proportions with fly ash and limestone filler. After 3, 6, 12, 24, 36, 48 and 60 months of exposure, three or four specimens of each cement type were removed from the pond and washed with water. Their compressive strength and microstructure (X-ray diffraction, mercury intrusion pore-symmetry, thermal analysis and scanning electron microscopy) were then measured. Sulphate-resistant Portland cement (SR-PC), found to be more susceptible to degradation due to its greater proportion of macro-pores and increased total porosity, was found not to be suitable for use with livestock. After 60 months of immersion in the pig slurry medium, CEM II-A (40.3\%) mortar retained the greatest compressive strength. Mortars with less than $20 \%$ replacement of cement by fly ash were found to be the most durable, with the most suitable mechanical behaviour.
\end{abstract}

\section{Introduction}

Pig farming makes up 39\% of the global production of meat for human consumption (FAO, 2011). In Europe, Spain, with 25.3 million animals (MARM, 2010), is the second largest producer, behind Germany. As with poultry farming, this sector employs highly intensive farming methods combined with large farms, declining in number.

Farming intensity has led to an increase in environmental problems caused by the generation of large quantities of manure and slurry. Although pig slurry is used as fertiliser (Sánchez \& González, 2005), dealing with this waste is complicated by its excessive concentration in certain areas
(European Union, 1991). Environmental problems have occurred as a result of insufficient land being available for the spreading of the amount of fertiliser produced (Daudén, Quílez, \& Vera, 2004; Yagüe \& Quílez, 2010). It has become necessary to store waste in pools or containers made from concrete or mortar-coated brick.

The use in farms of concrete, either poured on site or prefabricated, is common for feeding troughs. Such concrete is damaged by direct contact with slurry (De Belie et al., 2000).

In farm buildings throughout Europe the use of sulphateresistant Portland cement, pozzolanic cement and silica fume is common (Bertron, Escadeillas, \& Duchesne, 2004). In Spain, the cement recommended for agriculture is 
sulphate-resistant Portland cement, along with cement that contains added fly ash (RC-08, 2009; Sánchez, Garcimartín, Jofré, \& Burón, 2010). These latter are the most commonly used because of their high performance (Ahmaruzzaman, 2010) and low cost. For that reason, the cements chosen for our testing were a sulphate-resistant Portland cement and 3 cements with varying fly-ash contents.

In general terms pig slurry, a liquid of a complex and variable composition, contains water (90\%) and a small fraction of dry matter, basically made up of organic and mineral matter and bacteria. Bacteria transform the organic matter principally into acetic and butyric acids of variable concentrations along with various sulphate salts from the urea (Calleja, 2005; De Belie et al., 2000). The variability of slurry composition is influenced by factors related to the method of farming and others such as the breed, age or physiology of animals (Moral et al., 2005; Yagüe, Bosch-Serra, \& Boixadera, 2012; Yagüe, Guillen, \& Quílez, 2011). The result is a compound with a very heterogeneous $\mathrm{pH}$. Zhang, Prince, Xin, and Harmon (1994) found $\mathrm{pH}$ varied between 5.3 and 6.9, while Bonmatí (2001) found it varied between 6.5 and 8.7, Sánchez and González (2005) found it varied 7.2 and 8. Very similar values were found by Moral et al. (2005) and Sánchez, Massana, Garcimartín, and Moragues (2008). These $\mathrm{pH}$ values cause slurry to be considered of zero or negligible corrosiveness to cement and its derivatives, as stated by Spanish structural concrete standards (MOPU, 2008). However, other factors such as the high concentration of ammoniacal nitrogen, the presence of acids such as acetic, propionic and isovaleric acid, or potentially corrosive substances such as chlorides, should be taken into consideration. In accordance with the concentrations determined by Bonmatí (2001) and Sánchez et al. (2008) slurry can be classified as a highly corrosive substance.

Various authors have studied the aggressive effects of slurry on cement, mortar and concrete. However, the majority of studies were made using artificial solutions and under laboratory conditions (Bertron, Duchesne, \& Escadeillas, 2005a, 2005b). The most commonly used solutions have been of acetic acid or a combination with lactic acid (De Belie et al., 2000; Larreur-Cayol, Bertron, \& Escadeillas, 2011). Other researchers have used ammonium sulphate (Assaad, Jofriet, \& Hayward, 2008a, 2008b) or sodium sulphate (Jofriet, Assaad, Negi, \& Hayward, 2004). They have also used strong acids such as nitric (Pavlik, 1996) or sulphuric acid (Monteny, De Belie, Vincke, Verstraete, \& Taerwe, 2001; Monteny et al., 2000). In addition, exposure to the aggressive compound was not usually longer than 12 months.
The novelty of this work is that it used natural pig slurry in a natural media throughout a period of 5 years of exposure.

The aim was to determine the behaviour of different mortars to be employed in livestock media and to analyse the corrosiveness of pig slurry towards these cement mortars. To carry out this objective a large number of characterisation techniques were used, including measurements of mechanical strength, X-ray diffraction, thermal analysis, mercury intrusion pore-symmetry and scanning electron microscopy.

\section{Materials and methods}

\subsection{Cements}

To carry out this study mortar samples were immersed in the pig slurry media. Mortar samples were made from four types of cements: sulphate-resistant CEM I-SR 42.5N (CEM-I) Portland cement, and three cements blended with different proportions of fly ash and limestone filler: CEM II/A-V 42.5R (CEM II-A), CEM IL/B-M(V-L) 32.5N (CEM II-B) and CEM IV/B-V 32.5N (CEM-IV) (UNE-EN 197-1:2000). The different components used in these cements are shown in Table 1.

The chemical composition of the four cements is shown in Table 2.

\subsection{Aggressive medium}

The aggressive medium used was pig slurry from a farm storage lagoon at Etreros in the central Spanish province of Segovia, where the mean summertime relative humidity is $48 \%$ and the mean temperature is $20^{\circ} \mathrm{C}$. Values for the rest of the year are $75 \%$ and $9^{\circ} \mathrm{C}$, respectively. The area has a mean of 56 days of frost per year. The slurry has a variable composition and changes over time. Different sampling was carried out every 3 or 6 months throughout the experiment. The principal composition of this slurry is shown in Table 3.

The principal characteristics of pig slurry are, firstly, a very high concentration of ammoniacal nitrogen, between 500 and $1200 \mathrm{mgl}^{-1}$, from the hydrolysis of organic nitrogen which in anaerobic conditions produces ammonia; secondly, the presence of chloride ions, that produce a salinity similar to seawater; third, the amount of acetic, propionic and isovaleric acids. Also, the $\mathrm{pH}$ value, between 7.4 and 8.2 , makes it possible to consider this medium as corrosive towards cement, which has a pH of around 12.5 (Fernández Cánovas, 2007). According to the Spanish Standard EHE (MOPU, 2008), pig slurry could be catalogued as a medium with a very low

\begin{tabular}{|c|c|c|c|c|c|}
\hline Designation & $\begin{array}{c}\text { Simplified } \\
\text { designation }\end{array}$ & Clinker & Fly ash & $\begin{array}{l}\text { Limestone } \\
\text { filler }\end{array}$ & Limestone \\
\hline CEM I-SR $42.5 \mathrm{~N}$ & CEM I & 96.2 & 0 & - & - \\
\hline CEM II/A-V 42.5R & CEM II-A & 81 & 16 & - & - \\
\hline CEM II/B-M(V-L) $32.5 \mathrm{~N}$ & CEM II-B & 70 & 20.4 & 6.4 & 3 \\
\hline CEM IV/B-V $32.5 \mathrm{~N}$ & CEM IV & 57.1 & 39.1 & - & 3.8 \\
\hline
\end{tabular}


Table 2 - Chemical and mineral composition of cements used (wt \%).

\begin{tabular}{|c|c|c|c|c|c|c|c|c|c|c|c|}
\hline Cement type & $\mathrm{CaO}$ & $\mathrm{SiO}_{2}$ & $\mathrm{Al}_{2} \mathrm{O}_{3}$ & $\mathrm{Fe}_{2} \mathrm{O}_{3}$ & $\mathrm{MgO}$ & $\mathrm{K}_{2} \mathrm{O}$ & $\mathrm{SO}_{3}$ & $\mathrm{Cl}$ & $\mathrm{Na}_{2} \mathrm{O}$ & CO free & Ignition loss \\
\hline CEM I & 64.4 & 19.1 & 3.9 & 4.7 & 1.3 & 0.7 & 3.1 & - & 0.2 & 2.1 & 2.6 \\
\hline CEM II-A & 48.21 & 35.35 & 5.67 & 3.6 & 1.74 & 1.35 & 2.23 & 0.008 & - & - & 1.78 \\
\hline CEM II-B & 51.36 & 24.80 & 9.19 & 3.25 & 2.14 & 1.41 & 2.58 & 0.006 & - & - & 1.75 \\
\hline CEM IV & 26.05 & 57.45 & 7.4 & 3.5 & 1.24 & 1.39 & 1.26 & 0.006 & - & - & 1.69 \\
\hline
\end{tabular}

Table 3 - Slurry composition: minimum, maximum and average values.

\begin{tabular}{|c|c|c|c|c|}
\hline & \multicolumn{3}{|c|}{ Slurry composition } \\
\hline & & Min. & Aver. & Max. \\
\hline \multicolumn{2}{|l|}{$\mathrm{pH}$} & 7.43 & 7.94 & 8.20 \\
\hline \multicolumn{2}{|c|}{ Conductivity (mS) } & 5.68 & 8.92 & 13.25 \\
\hline \multicolumn{2}{|c|}{ Redox Potential (mV) } & -304.00 & -169.38 & -71.00 \\
\hline \multicolumn{2}{|c|}{ Total solids $\left(\mathrm{mgl}^{-1}\right)$} & 4.07 & 5.87 & 7.19 \\
\hline \multicolumn{2}{|c|}{ Volatile solids $\left(\mathrm{mgl}^{-1}\right)$} & 2.04 & 2.95 & 3.98 \\
\hline \multicolumn{2}{|c|}{ Total nitrogen (\%) } & 0.06 & 0.12 & 0.20 \\
\hline \multicolumn{2}{|c|}{ Ammoniac nitrogen (\%) } & 0.05 & 0.09 & 0.12 \\
\hline \multicolumn{2}{|c|}{ Sulphurs (mg l-1) } & 5.36 & 71.32 & 105.00 \\
\hline \multicolumn{2}{|c|}{ Bicarbonates (mg $1^{-1}$ ) } & 3.38 & 5.85 & 10.55 \\
\hline \multirow[t]{2}{*}{ Anions } & Sulphurs $\left(\mathrm{mg} \mathrm{l}^{-1}\right)$ & 0.00 & 4.51 & 9.70 \\
\hline & Chlorides $\left(\mathrm{mg}^{-1}\right)$ & 61.00 & 453.04 & 1388.00 \\
\hline \multirow[t]{3}{*}{ Acids } & Acetic $\left(\mathrm{mgl}^{-1}\right)$ & 32.55 & 153.79 & 286.70 \\
\hline & Propionic $\left(\mathrm{mg} \mathrm{l}^{-1}\right)$ & 0.00 & 40.96 & 124.60 \\
\hline & Isovaleric $\left(\mathrm{mgl}^{-1}\right)$ & 0.00 & 2.15 & 3.50 \\
\hline
\end{tabular}

corrosiveness. Due to heterogeneity, it has been very difficult to establish the corrosiveness of pig slurry towards mortar and concrete.

\subsection{Experimental procedure}

The test was conducted in an experimental pond of $100 \mathrm{~m}^{3}$ located close to the working farm storage pond. A total of 112 samples of prismatic specimens $(40 \times 40 \times 160 \mathrm{~mm})$ with water/cement ratio of 0.5 and a sand/cement ratio of $3 / 1$ were prepared for each type of cement, according to specifications of European Standards UNE-EN 197-1:2000. The specimens were broken out of their moulds after $24 \mathrm{~h}$ and cured in water during $28 \mathrm{~d}$ at $22 \pm 2^{\circ} \mathrm{C}$. After curing, for each cement, three samples were used to measure mechanical strength (compressive strength), while another sample was employed for micro-structural characterisation. The rest of samples were kept in the pig slurry media at $1 \mathrm{~m}$ depth from day one for up to 60 months. After 3, 6, 12, 24, 36, 48 and 60 months of exposure, three or four specimens of each cement type were removed from the pond and washed with water, then immersed in water during $48 \mathrm{~h}$ to achieve stabilisation.

During the first year three samples were used to measure mechanical characteristics. For the rest of experimental periods two samples were used. In all cases another sample was used for micro-structural characterisation.

Compressive strength testing was conducted to European Standard EN196-1:1996. Variance analysis of data was carried out with the ANOVA process of StatGraphics v.5.1 (2002). For data analysis the model included the dependent variable "compression" and, as independent factors, "cement" and "time" and their interaction. The method used to discriminate among the means was Fisher's least significant difference (LSD) procedure $(p<0.05)$.

Mortar microstructure characterisation included mercury intrusion porosity (MIP) and X-ray diffraction (DRX). The specimens were obtained from the external face of the sample. Mercury intrusion porosity (MIP) tests were carried out on a mercury porosimetry, model Autopore IV 9500 brand Micromeritics Instrument Corporation, that operates at pressures of up to $228 \mathrm{MPa}$ and covers pore diameters of from 175 to $0.006 \mu \mathrm{m}$. Each of the $3 \mathrm{~g}$ specimens was dried for $48 \mathrm{~h}$ at a temperature of $22 \pm 2{ }^{\circ} \mathrm{C}$ and a relative humidity of $50 \%$. The

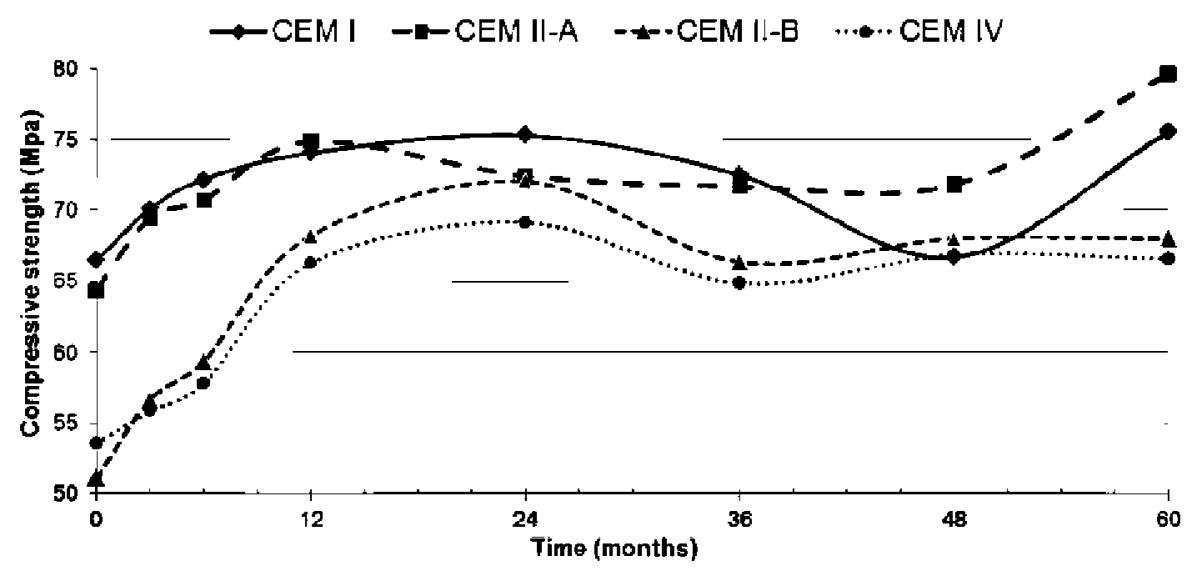

Fig. 1 - Variation of compressive strength over time. 
Table 4 - Table of least squares means for compressive strength (MPa).

\begin{tabular}{|c|c|c|c|c|c|}
\hline Level & Count & Mean & $\begin{array}{c}\text { Standard } \\
\text { error }\end{array}$ & $\begin{array}{c}\text { Lower } \\
\text { limit }\end{array}$ & $\begin{array}{l}\text { Upper } \\
\text { limit }\end{array}$ \\
\hline Grand mean & 78 & 67.43 & & & \\
\hline \multicolumn{6}{|l|}{ Cement } \\
\hline CEM I & 20 & $71.58^{\mathrm{a}}$ & 0.3527 & 70.87 & 72.29 \\
\hline CEM II-A & 19 & $71.86^{\mathrm{a}}$ & 0.3614 & 71.13 & 72.59 \\
\hline CEM II-B & 20 & $63.69^{\mathrm{b}}$ & 0.3527 & 62.98 & 64.40 \\
\hline CEM IV & 19 & $62.60^{\mathrm{b}}$ & 0.3614 & 61.87 & 63.32 \\
\hline SEM & & 0.3569 & & & \\
\hline \multicolumn{6}{|c|}{ Time (months) } \\
\hline 0 & 8 & $58.88^{\mathrm{a}}$ & 0.5464 & 57.78 & 59.98 \\
\hline 3 & 12 & $62.99^{\mathrm{b}}$ & 0.4461 & 62.09 & 63.89 \\
\hline 6 & 12 & $65.00^{\mathrm{b}}$ & 0.4461 & 64.11 & 65.90 \\
\hline 12 & 12 & $70.83^{c, d}$ & 0.4461 & 69.93 & 71.73 \\
\hline 24 & 10 & $72.20^{\mathrm{d}}$ & 0.4988 & 71.19 & 73.20 \\
\hline 36 & 8 & $68.82^{\mathrm{C}}$ & 0.5464 & 67.72 & 69.92 \\
\hline 48 & 8 & $68.33^{\mathrm{C}}$ & 0.5464 & 67.23 & 69.43 \\
\hline 60 & 8 & $72.41^{\mathrm{d}}$ & 0.5464 & 71.31 & 73.51 \\
\hline SEM & & 0.4940 & & & \\
\hline
\end{tabular}

Factors with different superscript $(a, b, c, d)$ indicate significant differences. SEM is the standard error of the mean

samples were taken from one of the exposed faces of the specimen and tested after reaching a constant weight, to an accuracy of $0.01 \mathrm{~g}$. Sample weight was stabilised in an oven at $40^{\circ} \mathrm{C}$.

$\mathrm{X}$-ray diffraction analysis was conducted by the Spanish National Research Council's Materials Science Institute on powder prepared by crushing samples after thorough drying at $40^{\circ} \mathrm{C}$. A Cu $\mathrm{K} \alpha$ cathode was used and the exposure time was $1 \mathrm{~min}$.

In order to complete the micro-structural characterisation after 60 months of exposure, a thermo-gravimetric analyses (TGA) and scanning electron microscopy (SEM) were carried out. Thermo-gravimetric analyses were carried out using a simultaneous thermal analyser, model STA 409 CD brand Netzsch loaded with Data thermal analysis system controller TASG 414/4 software. Samples (maximum amount to fill the crucible) were heated to $1050^{\circ} \mathrm{C}$ at a rate of $4^{\circ} \mathrm{C} \mathrm{min}{ }^{-1}$ in an inert atmosphere $\left(\mathrm{N}_{2}\right)$ and subsequently cooled at $10^{\circ} \mathrm{Cmin}^{-1}$. The digital scanning electron microscope (SEM) used was a JOEL model JSM 5400, fitted with a solid state backscattered detector and a Z-Ray microanalyses LINK-ISIS EDX.

\section{Results and discussion}

\subsection{Compressive strength}

The evolution of compressive mechanical strength over time is shown in Fig. 1. It can be seen that the four mortars showed an initial increase from 0 days to 24 months of pig slurry exposure. In all cases, the mortars reached values of about 70-75 MPa. The two mortars with the highest proportion of fly ash (CEM II-B and CEM IV) have lower values, around $72 \mathrm{MPa}$ and $69.1 \mathrm{MPa}$, respectively. This behaviour could be related with the mechanical resistance classification of these mortars; CEM I and CEM II-A have, at $28 \mathrm{~d}$, a value of $42.5 \mathrm{MPa}$, while CEM II-B and CEM IV have, at $28 \mathrm{~d}$, a value of $35.2 \mathrm{MPa}$.

Over time there were significant variations in the properties of the mortars. In the case of CEM II-B and CEM IV, their mechanical strength decreased from 69 and $72 \mathrm{MPa}$ to 64 and $63 \mathrm{MPa}$, respectively, constant values until the end of 60 months of exposure. Different behaviour could be observed in the two other mortars; for CEM IV the maximum values of compressive strength were similar at 24 and 60 months. After 60 months of exposure, the value for CEM II-A reached $80 \mathrm{MPa}$, the highest among the mortars.

With these types of mortars, there are two factors that can influence their behaviour throughout time. These factors are the type of cement and length of exposure. Therefore an analysis of variance of the values of compressive strength of the samples was carried out. Average values for this study are shown in Table 4 . Both factors have a statistically significant effect with a $P$ value less than 0.05

To avoid the effect that the class of cement has on the evolution of the mechanical strength of these mortars, a figure to represent the percentage change in the compressive strength of four mortars was drawn (Fig. 2).

As can be seen from Fig. 2, the highest increases occurred at 24 months of exposure except for CEM II-A. At this point, the maximum increase ( $36.3 \%$ compared to control), occurred in the

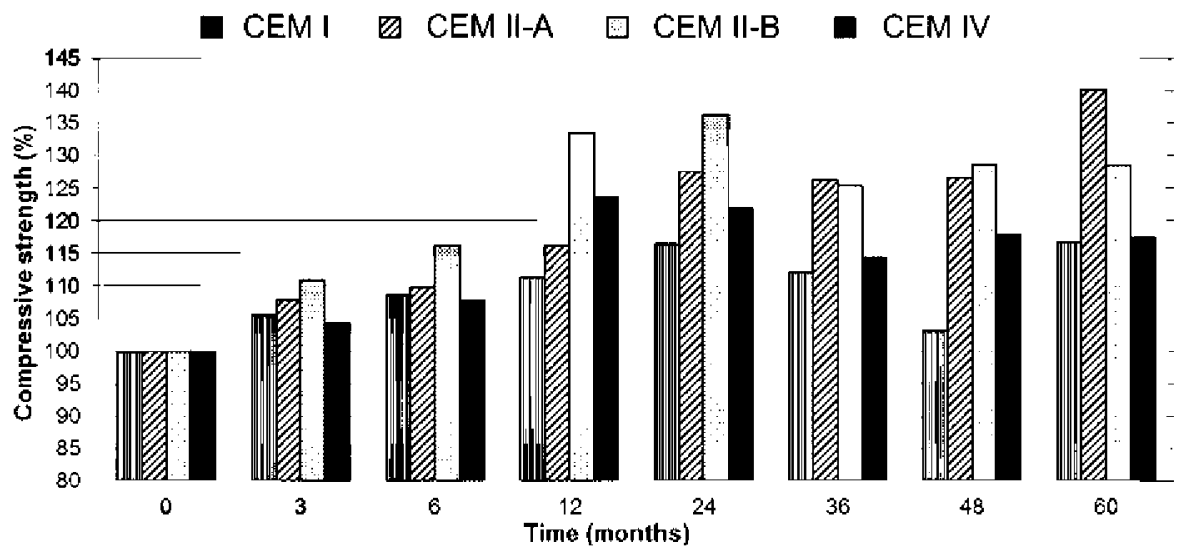

Fig. 2 - Percentage variation in compressive strength over time. 


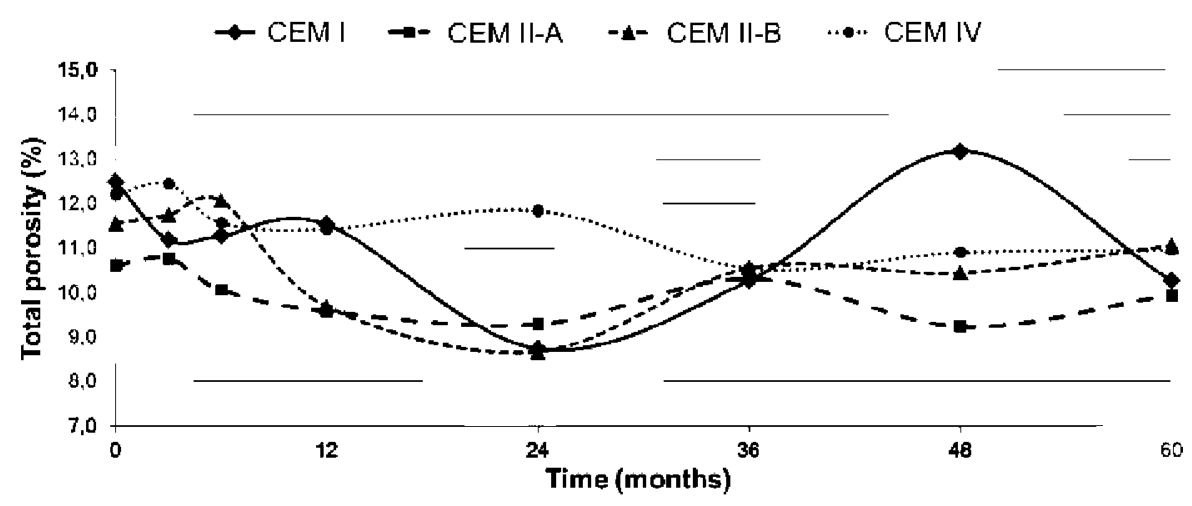

Fig. 3 - Evolution of total porosity versus time of exposure.

mortar of cement CEM II-B, whereas CEM II-A mortar achieved an increase of $28 \%$ and CEM IV of $22 \%$. The smallest increase was found in CEM I cement with 16\%. From 24 to 60 months, there was a change in tendency of the four samples. At 60 months of immersion in the pig slurry medium, the maximum positive change, $40.3 \%$, occurred in mortar CEM II-A; while in CEM II-B the value was $29 \%$, and CEM IV and CEM I values increased around $17 \%$. Greatest gains in strength, up to $80 \mathrm{MPa}$, occurred in CEM II-A mortar, which has a strength class of 42.5 and replacement of cement by fly ash of less than $20 \%$.

However, the development of mechanical strength varied among mortars with fly ash. This may be, firstly, because the pozzolanic reaction is determined by the amount of portlandite available; thus, in the presence of large amounts of ash, access to portlandite may be limited (Papadakis, 1999), and secondly, because part of the ash can act as an inert material (Sivasundaram, Carette, \& Malhorta, 1991), ensuring greater resistance in the long term. The work developed by Molina Bas (2008) compared the mechanical strength of concrete with low content of binder and various ash contents, obtaining a greater coefficient of efficiency when ash content was limited to $15 \%$. This result agrees with that obtained in the present work, since CEM II-A, with an ash content of $16 \%$, had the highest value of resistance to 60 months of exposure.

Development of mechanical strength in these materials possibly may be related to two mechanisms: firstly, to the
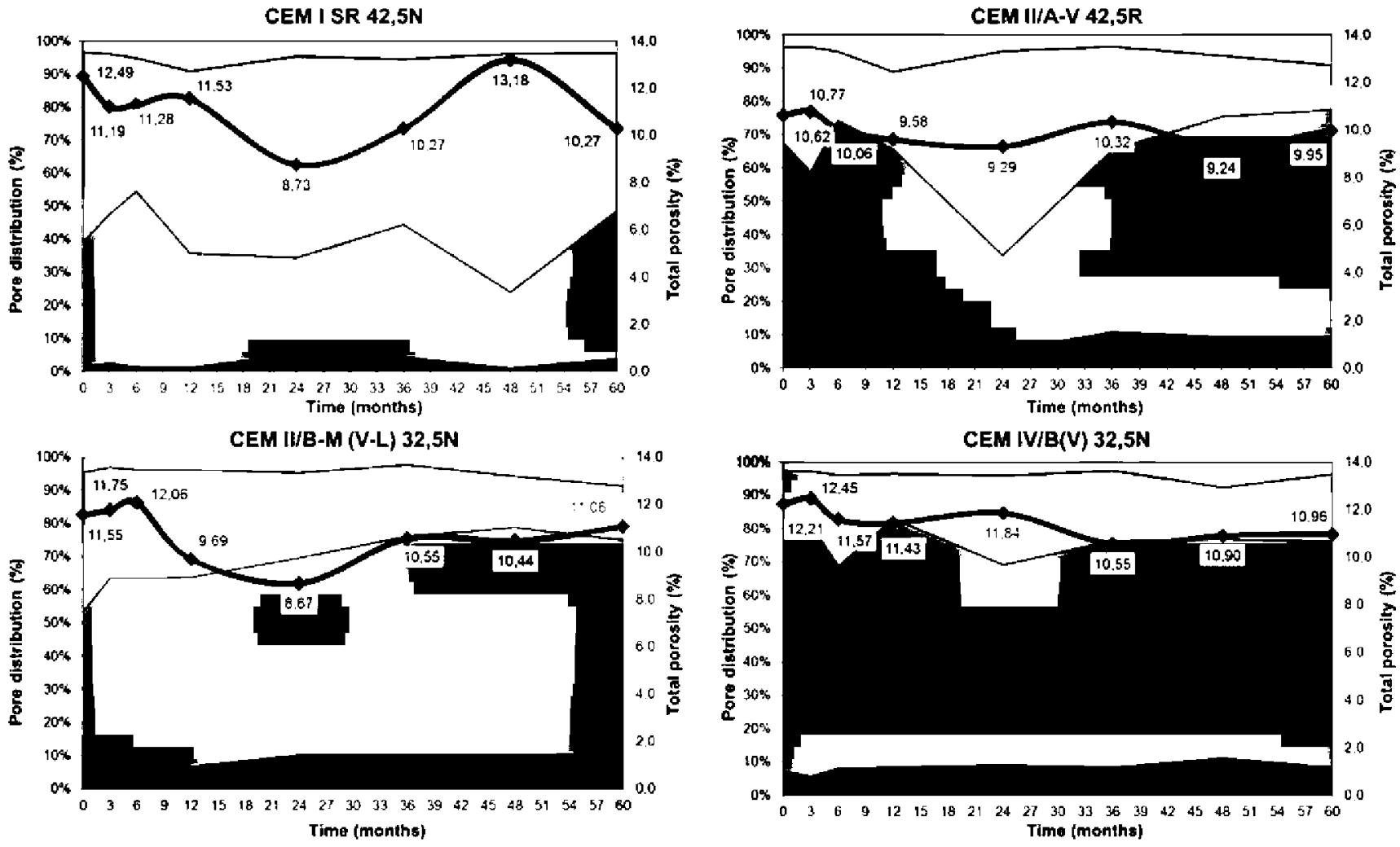

$\square<\varnothing<10 \mathrm{~nm} \quad \square 10<\varnothing<50 \mathrm{~nm} \quad \square 50 \mathrm{~nm}<\varnothing<10 \mu \mathrm{m} \quad \square \varnothing>10 \mu \mathrm{m}$ - Total porosity

Fig. 4 - Evolution of pore size distribution with time. 

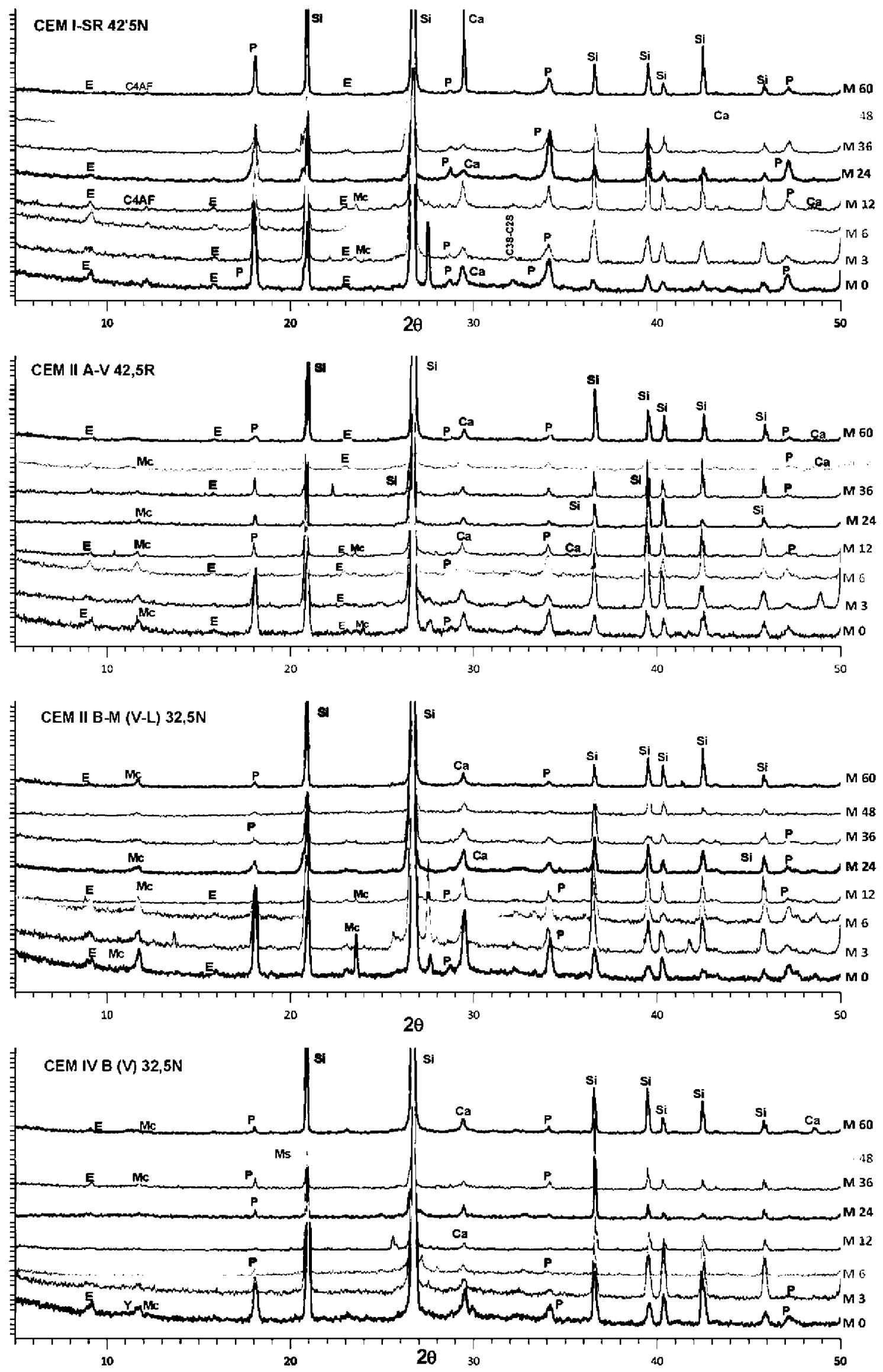

Fig. 5 - Evolution of the diffraction graphs of the 4 mortars studied with time. 

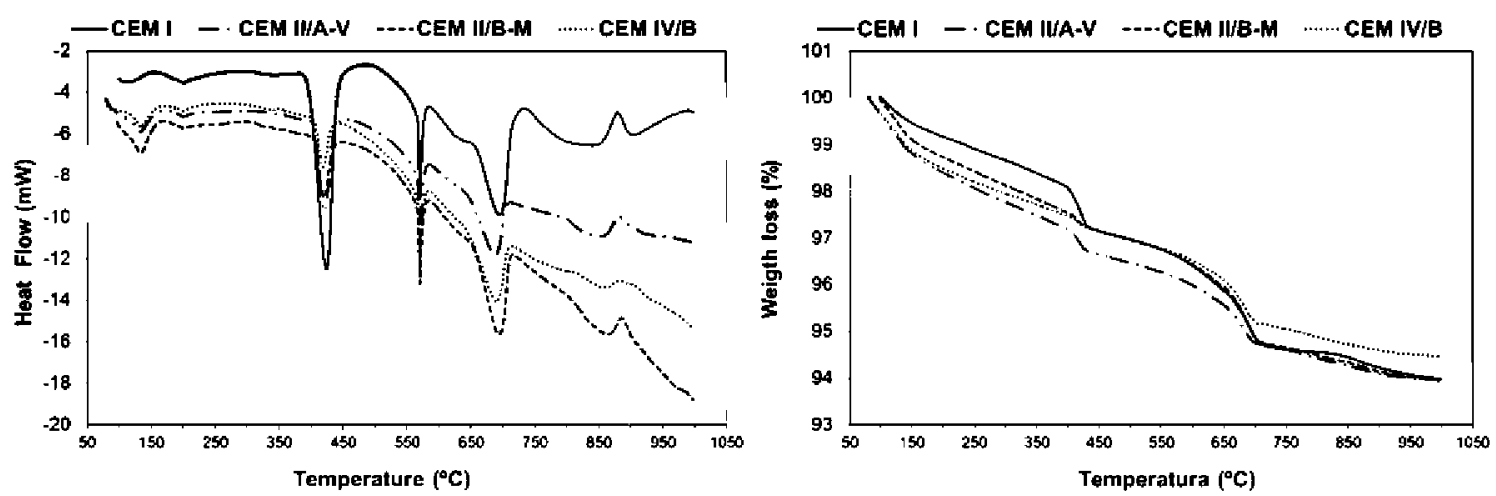

Fig. 6 - Diagrams of the differential thermal analysis (TG and DSC) of the 4 cement mortars immersed in slurry for 60 months.

hydration of cement over time, and secondly, to the pozzolanic reaction of fly ash (Wang, Zhang, \& Sun, 2004). For example, in the case of CEM I mortar, its profile of evolution of compressive strength could be related with the dissolution of the crystalline phase (see Fig. 5) due to the corrosiveness of the pig slurry media (Sánchez, Moragues, Massana, Guerrero, \& Fernandez, 2009).

However, the development of mechanical strength among mortars with replacement by fly ash is different. This may be because, the pozzolanic reaction is determined by the amount of portlandite available in the microstructure and by the ionic strength and $\mathrm{pH}$ of the pore solution of mortar (Guerrero, Hernández, \& Goñi, 2000; Moragues, Macías, Andrade, \& Goñi, 1989; Moragues, Macías, Andrade, \& Losada, 1988). Therefore the highest compressive strength was found in CEM II-A mortar (fly-ash content of $16 \%$ ), with a large amount of portlandite and a pore solution with ideal conditions for the pozzolanic reaction. This behaviour confirms results obtained by other authors (Molina Bas, 2008; Papadakis, 1999; Sivasundaram et al., 1991) who found that greater amounts of fly ash in cement can act as inert material impeding the development of greater compressive strength.

\subsection{Mercury intrusion pore-symmetry (MIP)}

The evolution of total porosity of the four mortar samples over 60 months of exposure is presented in Fig. 3. Initially ( 0 days exposure), the maximum value of total porosity was found in CEM I (12.5\%) and the minimum in CEM II-A (10.6\%). With length of exposure, total porosity decreased in all cases until 24 months, reaching the lowest values of around $9 \%$, with the exception of CEM IV mortar with a value of total porosity of $12 \%$. However, with increased length of exposure, there was a reversal in the value of total porosity; the mortar with the greatest amount of fly ash reached the lowest porosity, $10.96 \%$, while the rest of mortars increased their values to around $11 \%$.

Total porosity results were consistent with those obtained for compressive mechanical strength. In general, an inverse correlation was observed between the value of total porosity and compressive strength (Taylor, 2003). But there were some exceptions, such as the case of CEM II-A cement mortar, between 24 and 60 months, or CEM IV cement mortar. These show slight decreases in porosity values and unchanged compressive mechanical strength. These differences may be explained by the evolution of pore size distribution (Fig. 4). To

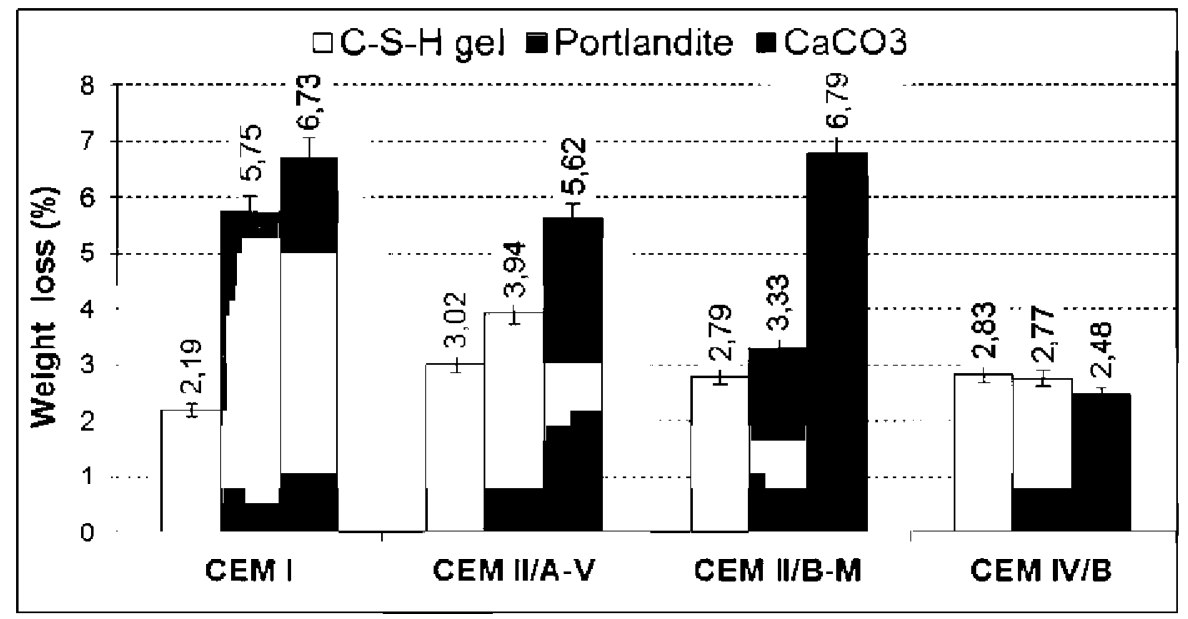

Fig. 7 - Percentage of weight loss of $\mathrm{C}-\mathrm{S}-\mathrm{H}$ gel, portlandite and $\mathrm{CaCO}_{3}$ of the hydrated cement in the 4 cement mortars immersed in slurry for 60 months. 


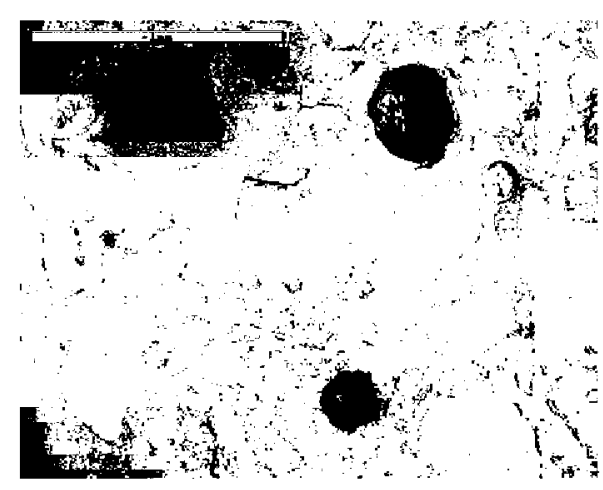

CEM I

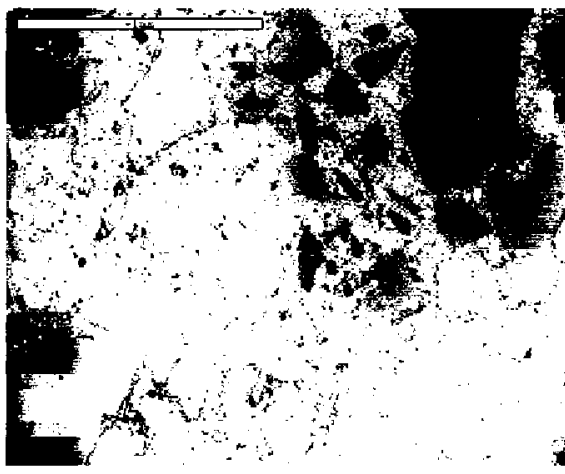

CEM II-B

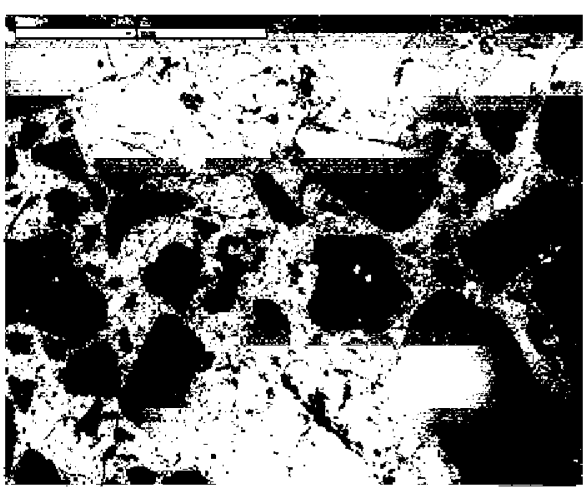

CEM II-A

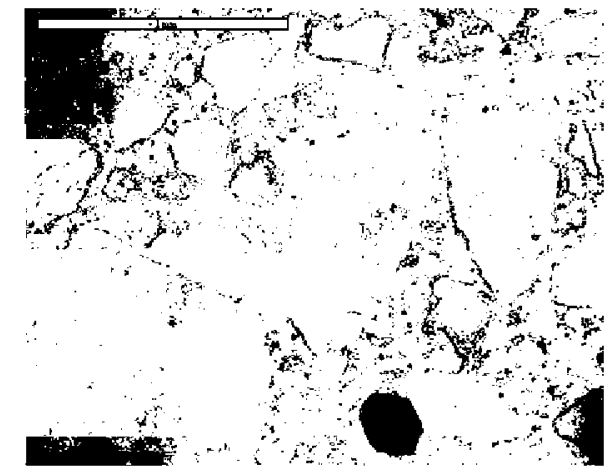

CEM IV

Fig. 8 - Microphotographs $(\times 50)$ of mortars after 60 months' immersion in slurry.

study pore size distribution the Mindess classification was adapted (Mindess, Young, \& Darwin, 2003). Four pore size ranges were identified (Massana Guitart, 2011): macro-pores $(>10 \mu \mathrm{m})$, large capillaries $(50 \mathrm{~nm}-10 \mu \mathrm{m})$, medium capillaries $(10-50 \mathrm{~nm})$ and small capillaries $(5-10 \mathrm{~nm})$. Large and medium capillaries influence the mechanical strength and permeability of the material, while small capillaries are associated with $\mathrm{C}-\mathrm{S}-\mathrm{H}$ gel pores.

Pore size distribution in CEM I cement mortar was remarkably different from that of mortars with replacement by fly ash (Fig. 4). Throughout exposure, CEM I mortar had a high percentage of large capillaries $(50 \mathrm{~nm}-10 \mu \mathrm{m})$ and a low proportion of small capillaries $(5-10 \mathrm{~nm})$. There was a significant increase in total porosity in this mortar over time, reaching $13.2 \%$ at 48 months, accompanied by an increase in the proportion of large capillaries. This may be due to leaching processes in cement that leads to a deterioration of compactness of the material.

Evolution of pore size distribution in mortars with a partial replacement by fly ash was very different compared with mortar without fly ash. In this case, there were a large number of pores in the range below $50 \mathrm{~nm}$. In general, throughout exposure there was a tendency to refine the microstructure due principally to two processes in these samples: both activation of the pozzolanic reaction and an acceleration of hydration reactions as a consequence of the characteristics of this pig slurry medium.

Variations observed in pore size distribution were not accompanied by changes in total porosity. This fact was noted in the case of CEM II-A at 24 months, where total porosity was around $9.3 \%$, practically the lowest throughout the total exposure period, and with a large number of pores $>50 \mathrm{~nm}$. This phenomenon is probably due to the dissolution of crystalline phases such as portlandite and ettringite (see Fig. 5), producing an opening of pore distribution, not reflected in the total porosity. After 36 months a new refinement of pore size distribution in this mortar was observed probably due to a late pozzolanic reaction produced by the presence of various ions and the ionic strength of the pig slurry media. (Guerrero et al., 2000).

\subsection{X-ray diffraction analysis (XRD) and thermal} gravimetric analysis (TGA)

XRD patterns and TG and DSC curve profiles of the CEM I, CEM II-A, CEM II-B and CEM IV hydrated phases immersed after 60 months in pig slurry media are shown in Figs. 5 and 6.

XRD patterns for all samples exposed to the corrosive solution revealed the existence of substantial changes in all samples. The main crystalline phases present in the four mortars at 0 time (reference time) were: ettringite $\left(\mathrm{C}_{6} \mathrm{As}_{3} \mathrm{H}_{32}\right)$ (JCPDS 41-1451), calcite $\left(\mathrm{CaCO}_{3}\right)$ (JCPDS 5-586), portlandite $\left(\mathrm{Ca}(\mathrm{OH})_{2}\right)$ (JCPDS 44-1481), di- and tri-calcium silicate $\left(\mathrm{C}_{2} \mathrm{~S}\right.$ and $\mathrm{C}_{3} \mathrm{~S}$ ) in the 32-332 $\theta$ angular. Also in the case of CEM I mortar the presence of $\mathrm{Ca}_{4} \mathrm{Al}_{2} \mathrm{Fe}_{2} \mathrm{O}_{10}$ ( $\mathrm{C}_{4} \mathrm{AF}$ ) (JCPDS 74-1346) was discovered and as was the presence of calcium mono-carbo-aluminate in the rest of mortars with fly-ash additions. Crystalline phases present in these mortars vary with time of exposure.

Experimental data obtained from thermo-gravimetric analysis (TG) of the four mortars at the end of 60 months of 


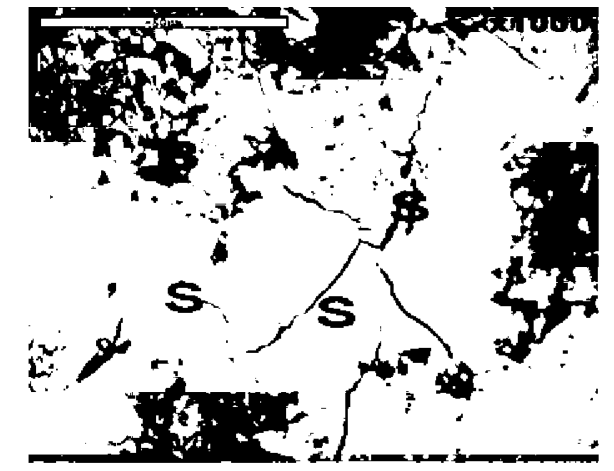

CEM I

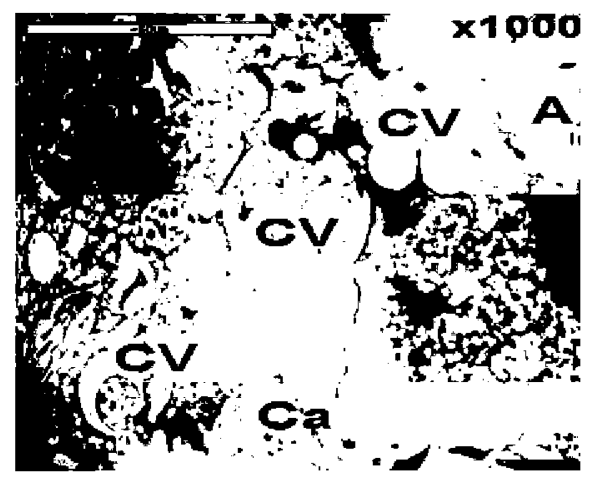

CEN II-B

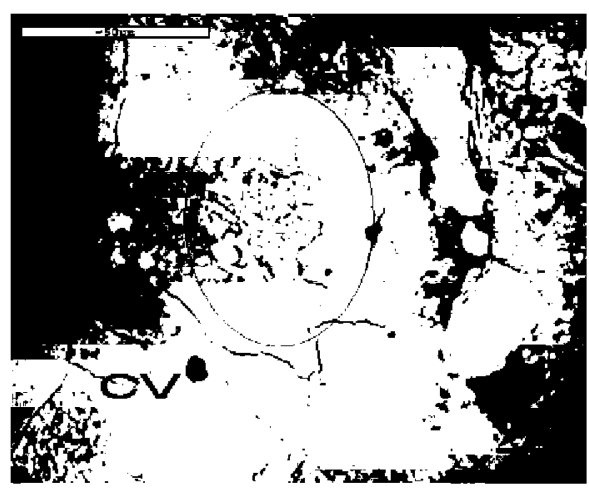

CINIIII-A

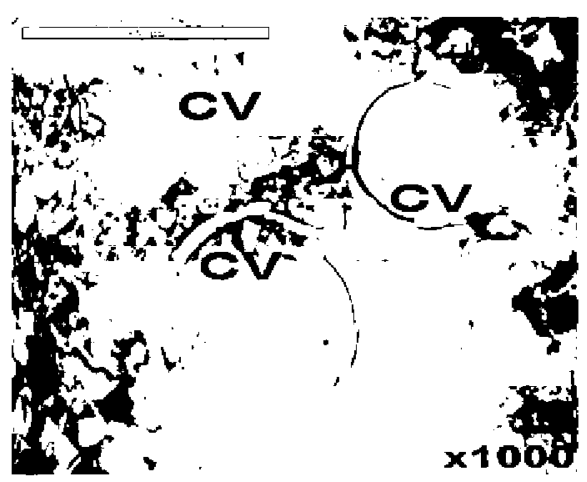

CENII

Fig. 9 - Microphotographs (enlargement indicated) of mortars after 60 months' immersion in slurry. $S=$ particles of di and tri-calcium silicate $\left(\mathrm{C}_{2} \mathrm{~S}\right.$ and $\left.\mathrm{C}_{3} \mathrm{~S}\right) ; \mathrm{B}=$ particles of $\mathrm{Ca}_{4} \mathrm{Al}_{2} \mathrm{Fe}_{2} \mathrm{O}_{10}\left(\mathrm{C}_{4} \mathrm{AF}\right) ; \mathrm{CV}=$ fly-ash unreacted.

immersion in pig slurry medium, allowed us to quantify the phases formed during hydration: $\mathrm{C}-\mathrm{S}-\mathrm{H}$ gel, sulphoaluminate phases like ettringite, portlandite $\left(\mathrm{Ca}(\mathrm{OH})_{2}\right)$. Also it was possible to quantify the amount of calcium carbonate or calcite $\left(\mathrm{CaCO}_{3}\right)$ formed during this study.

TG and differential scanning calorimetry (DSC) curve profiles of these mortars are shown in Fig. 6. As can be seen, a continuous mass loss between 25 and $350^{\circ} \mathrm{C}$ was observed in TG curves along with a peak with a maximum about $150^{\circ} \mathrm{C}$ in the corresponding DSC curve, which is due to the release of water molecules from the $\mathrm{C}-\mathrm{S}-\mathrm{H}$ gel and hydrated product decomposition. The second and well-defined mass loss was occurred between 350 and $550^{\circ} \mathrm{C}$ and peaked with a maximum at $420^{\circ} \mathrm{C}$, due to the water molecules released from the portlandite decomposition. The third mass loss occurred between 550 and $900^{\circ} \mathrm{C}$, and produced a peak at $700^{\circ} \mathrm{C}$ in the DSC curve, due to the release of $\mathrm{CO}_{2}$ molecules from calcite and carbo-aluminate decomposition. The zone peak between 570 and $573^{\circ} \mathrm{C}$ in the DSC curve was assigned to crystalline inversion of non-reacted quartz $\left(\mathrm{SiO}_{2}\right)$, from aggregates in the concrete, present in all samples.

Figure 7 shows the quantification of the different hydrate and carbonate phases present in mortars. This quantification was difficult due to overlapping and to the presence of sand in samples.

As can be seen in Fig. 7, the presence of fly ash (mortars with CEM II-A, CEM II-B and CEM IV) contributed to the acceleration of hydration of cement particles and produced an increase of percentage of weight loss of $\mathrm{C}-\mathrm{S}-\mathrm{H}$ gel from $3.02 \%$ to $2.79 \%$ versus $2.19 \%$ in the case of mortar CEM I. Greatest differences could be observed in the case of CEM II-A versus CEM I. Weight loss from portlandite and calcite could be related to the initial content of calcium oxide in cements. These values were highest in CEM I and CEM II-B, and lowest in CEM IV.

Evolution of X-ray diffraction patterns of four mortars immersed during 60 months in pig slurry medium (Fig. 5) showed that for CEM I mortar, until 24 months there was a decrease in the reflections of ettringite, portlandite and calcite indicating dissolution of these phases probably due to a variation in the $\mathrm{pH}$ of pore solution. This effect is related to an increase of total porosity from 12.49 to $13.13 \%$, together with an increase of pores larger than $50 \mathrm{~nm}$. The presence of these larger pores opens up the microstructure, favouring the sequestration of $\mathrm{CO}_{2}$ produced by fermentation of the organic components of pig slurry. The reaction between this $\mathrm{CO}_{2}$ and $\mathrm{Ca}^{2+}$ ions from the dissolution of the hydrated phase of cement could form a calcite layer with a protector effect (Bertron et al., 2004; Gaztañaga, 1996; Llorente, 2008). Due to the presence of this layer, reflections of calcite appear greatest at 60 months of immersion, in accordance with the amount of calcite calculated by TG analysis of $6.72 \%$.

Mortars with fly-ash additions behave differently. Reflection intensities from calcite, ettringite and portlandite almost disappear. It is important to emphasise the presence of calcium mono-carbo-aluminate until 60 months in mortar CEM II-B; this is in agreement with the amount of calcite compounds quantified in TG analysis and with the refinement 
of microstructure (about of $70 \%$ of total porosity) and a greater value of compressive strength, that together contribute to increased durability over time.

\subsection{Scanning electron microscopy (SEM)}

To complete the study of the four mortars immersed in pig slurry medium during 60 months a brief scanning electron microscopy study was carried out. The most relevant micrographs are shown in Figs. 8 and 9. In spite of the variations observed in the four mortars as to porosity, evolution of mechanical strength and the presence and dissolution of crystalline phases, the aspect of the microstructure is good. As can be seen in Fig. 8, after 5 years the microstructure appears without cracks, strain or any other sign of degradation of material.

The microstructure of CEM I differs from that of mortars with fly ash. As can be observed in Fig. 9, in CEM I it is possible to detect the presence of particles of di- and tri-calcium silicate $\left(\mathrm{C}_{2} \mathrm{~S}\right.$ and $\left.\mathrm{C}_{3} \mathrm{~S}\right)(\mathrm{S})$ and $\mathrm{Ca}_{4} \mathrm{Al}_{2} \mathrm{Fe}_{2} \mathrm{O}_{10}\left(\mathrm{G}_{4} \mathrm{AF}\right)(\mathrm{B})$, which corroborated the XRD pattern in which both phases appeared during time of exposition.

The microstructure aspect of mortars with fly ash differed in relation to the processes that took place in these samples over the 5 years immersed in pig slurry media. These observations confirmed that large amounts of fly ash do not ensure greater mechanical strength or stronger pozzolanic reaction.

In CEM IV and CEM II-B it is possible to observe the remains of unreacted cenospheres of fly ash (CV), acting as inert material; however in the micrographs of CEM II-A fly ash (CV) can be seen to be totally integrated in the paste indicating a complete reaction process providing this mortar's greatest compressive strength after 5 years immersed in pig slurry media.

\section{Conclusions}

Throughout this study, the behaviour of different mortars exposed to pig slurry during five years were analysed. The aims were to measure the various changes that occurred in structures of mortars which come in contact with this manure, and in addition, to measure the degree of corrosiveness of this compound. To this end four different cement mortars often used in livestock were immersed. Analyses conducted show that all cements used had an acceptable behaviour (i.e. performance) when immersed in the pig slurry. However, sulphate-resistant Portland cement (CEM I, SR) is not advisable for use in a pig slurry media ( $\mathrm{pH}$ around 8, chloride ions, acetic, propionic and isovaleric acids). This cement is more susceptible to degradation due to its greater total porosity, larger proportion of large capillary macro-pores and lower compressive strength than mortars CEM II-A and CEM II-B. It is also less sustainable because of its higher clinker content, and it is more expensive that the other cements analysed. Therefore, the partial replacement of cement by fly ash $(<40 \%)$ improves durability and mechanical strength of the basic cement materials used in agricultural environments. The best mechanical behaviour, with an increase of around $40 \%$ in pig slurry media over five years, was found in cement mortars which have a fly-ash content of $20 \%$ (CEM II-A and CEM II-B). Scanning electron microscopy study showed that after 5 years, the microstructure appears without cracks, strain or any other sign of degradation of material. This may be due to two reasons: firstly, a calcite protective layer formed from the reaction of free calcium ions in the pore solution and $\mathrm{CO}_{2}$ dissolved in pig slurry that ensured mortar durability throughout time of immersion and secondly, that naturallyoccurring pig slurry is a compound of low corrosiveness.

It would be advisable to use eco-efficient mortars (with about $15 \%$ replacement of cement by fly ash) in agriculture and livestock facilities because they offer lower costs along with greater mechanical strength and durability.

\section{Acknowledgements}

The authors gratefully acknowledge the financial support of the Minister of Science and Technology Project BIA200914395-C04-04 and of the Spanish Ministry of Public Works projects $\mathrm{C} 14 / 2006$ and $\mathrm{C01} / 2007$. Also they wish to express their thanks for the financial support given by the Spanish Institute of Cement and its Applications (IECA).

\section{R E F E R E N C E S}

Ahmaruzzaman, M. (2010). A review on the utilization of fly ash. Progress in Energy and Combustion Science, 36, 327-363.

Assaad, V. F., Jofriet, J., \& Hayward, G. (2008a). Sulphate and sulphide corrosion in livestock buildings, part I: concrete deterioration. Biosystems Engineering, 99, 372-381.

Assaad, V. F., Jofriet, J., \& Hayward, G. (2008b). Sulphate and sulphide corrosion in livestock buildings, part II: reinforcing steel corrosion. Biosystems Engineering, 99, 382-389.

Bertron, A., Duchesne, J., \& Escadeillas, G. (2005a). Accelerated tests of hardened cement pastes alteration by organic acids: analysis of the pH effect. Cement and Concrete Research, 35, 155-166.

Bertron, A., Duchesne, J., \& Escadeillas, G. (2005b). Attack of cement pastes exposed to organic acids in manure. Cement and Concrete Composites, 27, 898-909.

Bertron, A., Escadeillas, G., \& Duchesne, J. (2004). Cement pastes alteration by liquid manure organic acids: chemical and mineralogical characterization. Cement and Concrete Research, 34, 1823-1835.

Bonmatí, A. (2001). Usos de l'energia tèrmica per a la millora del procés de digestió anaeròbia de purins de porc i per a la recuperació de productes d'interès. Tesis doctoral, Universitat de Lleida.

Calleja, J. (2005). The aggressive agents for concrete in agricultural, livestock and agroalimentary industries. In Proceedings of the Vth international symposium of concrete for a sustainable agriculture agro-, aqua- and community applications (pp. 139-152). San Lorenzo de El Escorial, Spain.

Daudén, A., Quílez, D., \& Vera, M. V. (2004). Pig slurry application and irrigation effects on nitrate leaching in Mediterranean soil lysimeters. Joumal of Environmental Quality, 33(6), 2290-2295.

De Belie, N., Lenehan, J. J., Braam, C. R., Svennerstedt, B., Richardson, M., \& Snock, B. (2000). Durability of building materials and components in the agricultural environment, part III: concrete structures. Journal of Agricultural Engineering Research, 76(1), 3-16.

European Union. (1991). Council directive 91/676/EEC of 12 December concerning the protection of waters against 
pollution caused by nitrates from agricultural sources. Official Journal of European Communities, L375, Brussels, Belgium.

FAO. (2011). FAOSTAT [Online]. Available at. Rome: FAO http:// faostat.fao.org/site/573/.

Fernández Cánovas, M. (2007). Hormigón (8th ed.). Madrid: Colegio de Ingenieros de Caminos, Canales y Puertos, Spain.

Gaztañaga, M. T. (1996). Influencia de la carbonatación en la microestructura de diferentes pastas de cemento hidratadas. Tesis doctoral, Facultad de Ciencias Químicas, Universidad Complutense de Madrid.

Guerrero, A., Hernández, M. S., \& Goñi, S. (2000). The role of the fly ash pozzolanic activity in simulated sulphate radioactive liquid waste. Waste Management, 20(1), 51-58.

Jofriet,J., Assaad, V.F. C., Negi, S. C., \& Hayward, G. L. (2004). Deterioration of reinforced concrete in farm buildings due to sulfate and sulfide attack. ASAE meeting paper no. 044093. St Joseph, Mich: ASAE.

Larreur-Cayol, S., Bertron, A., \& Escadeillas, G. (2011). Degradation of cement-based materials by various organic acids in agroindustrial waste-waters. Cement and Concrete Research, 41 , 882-892.

Llorente, I. (2008). Degradación de hormigones de altas y ultra altas prestaciones por aguas naturales: Análisis en función de diferentes escenarios de lixiviación. Tesis doctoral presentada en la Universidad Complutense de Madrid.

MARM. (2010). Guía de mejores técnicas disponibles del sector porcino. Spain: Ministerio de Medio Ambiente y Medio Rural y Marino, Gobierno de España.

Massana Guitart, J. (2011). Durabilidad de morteros de cemento en contacto con purines de cerdo. Tesis doctoral, Escuela Técnica Superior de Ingenieros Agrónomos, Universidad Politécnica de Madrid, España. Available at https://serviciosgate.upm.es/ tesis/tesis/6547.

Mindess, S., Young, J. F., \& Darwin, D. (2003). Concrete (2nd ed.). Upper Saddle River, NJ 07458: Prentice Hall, Pearson Education, Inc..

Molina Bas, O. I. (2008). La influencia de las cenizas volantes como sustituto parcial del cemento Portland en la durabilidad del hormigón. Tesis doctoral, Escuela Técnica Superior de Ingenieros de Caminos, Canales y Puertos, Universidad Politécnica de Madrid. Available at https://serviciosgate.upm. es/tesis/tesis/6055.

Monteny, J., De Belie, N., Vincke, E., Verstraete, W., \& Taerwe, L. (2001). Chemical and microbiological tests to simulate sulfuric acid corrosion of polymer-modified concrete. Cement and Concrete Research, 31, 1359-1365.

Monteny, J., Vincke, E., Beeldens, A., De Belie, N., Taerwe, L., Van Gemert, D., et al. (2000). Chemical, microbiological and in situ test methods for biogenic sulphuric acid corrosion of concrete. Cement and Concrete Research, 30, 623-634.

MOPU. (2008). Instrucción de Hormigón Estructural. Madrid, España: EHE, Ministerio de Fomento.

Moragues, A., Macías, A., Andrade, C., \& Goñi, S. (1989). Chemical equilibrium constants of the aqueous cement paste. Comparative study of synthetics and extracted solution. Materials Engineering, 1(2), 453-458.

Moragues, A., Macías, A., Andrade, C., \& Losada, J. (1988). Equilibria of the chemical composition of the concrete pore solution. Part II: calculation of the equilibria constants of synthetic solutions. Cement and Concrete Research, 18(3), 342-350.
Moral, R., Moreno-Caselles, J., Pérez-Murcia, M., PérezEspinosa, A., Rufete, B., \& Paredes, C. (2005). Characterization of the organic matter pool in manures. Bioresource Technology, 96, 153-158.

Papadakis, V. G. (1999). Effect of fly ash on Portland cement systems. Part I. Low calcium fly ash. Cement and Concrete Research, 29, 1727-1736.

Pavlik, V. (1996). Corrosion of hardened cement paste by acetic and nitric acids. Part III: influence of water/cement ratio. Cement and Concrete Research, 26(3), 475-490.

RC-08. (2009). Instrucción para la recepción de cementos. Madrid, Spain: Comisión permanente del cemento, Ministerio de Fomento, Secretaría General Técnica.

Sánchez, E., Garcimartín, M. A., Jofré, C., \& Burón, M. (2010). Manual para el empleo del hormigón en obras agrícolas. In Instituto español del cemento y sus aplicaciones (IECA). (Ed.), Hormigón y durabilidad en el medio agrícola (pp. 3-74). Madrid. España.

Sánchez, M., \& González, J. L. (2005). The fertilizer value of pig slurry. I: values depending on the type of operation. Bioresource Technology, 96, 117-193.

Sánchez, E., Massana, J., Garcimartín, M. A., \& Moragues, A. (2008). Mechanical strength and microstructure evolution of fly ash cement mortar submerged in pig slurry. Cement and Concrete Research, 38, 717-724.

Sánchez, E., Moragues, A., Massana, J., Guerrero, A., \& Fernández, J. (2009). Effect of pig slurry on two cement mortars: changes in strength, porosity and crystalline phases. Cement and Concrete Research, 39, 798-804.

Sivasundaram, V., Carette, G. G., \& Malhorta, V. M. (1991). Mechanical properties creep and resistance to diffusion of chloride ions of concretes incorporating high volumes of ASTM class F fly ashes from seven different sources. ACI Materials Journal, 88(4), 407-416.

Taylor, H. F. W. (2003). Cement chemistry (p. 459) (2nd ed.). London: Thomas Telford Publishing.

UNE-EN 197-1:2000. (2000). Composición, especificaciones y criterios de conformidad de los cementos comunes. Madrid. España: AENOR.

UNE-EN 196-1:1996. (1996). Métodos de ensayo de cementos. Parte 1: Determinación de resistencia mecánicas. España: AENOR.

Wang, A., Zhang, C., \& Sun, W. (2004). Fly ash effects II. The active effect of fly ash. Cement and Concrete Research, 34(11), 2057-2060.

Yagüe, M. R., Bosch-Serra, A. D., \& Boixadera, J. (2012). Measurement and estimation of the fertiliser value of pig slurry by physicochemical models: usefulness and constraints. Biosystems Engineering, 111, 206-216.

Yaguie, M. R., Guillen, M., \& Quilez, D. (2011). Effect of covers on swine slurry nitrogen conservation during storage in Mediterranean conditions. Nutrient Cycling in Agroecosystems, 90(1), 121-132.

Yagüe, M. R., \& Quílez, D. (2010). Response of maize yield, nitrate leaching, and soil nitrogen to pig slurry combined with mineral nitrogen. Journal of Environmental Quality, 39(2), 686-696.

Zhang, H., Prince, D., Xin, H., \& Harmon, J. D. (1994). Production and emission dynamics of manure gas in nursery swine rooms with shallow pits. ASAE international winter meeting, Chicago, Illinois, 13-16 December. 